\title{
PERLINDUNGAN DATA PRIBADI TERHADAP TINDAKAN PENYEBARAN SEX TAPE MENURUT HUKUM POSITIF DI INDONESIA
}

\author{
Moody R. Syailendra ${ }^{1}$ \\ ${ }^{1}$ Fakultas Hukum, Universitas Tarumanagara Jakarta \\ Email:moodys@fh.untar.ac.id
}

Masuk : 05-07-2021, revisi: 14-09-2021, diterima untuk diterbitkan : 14-09-2021

\begin{abstract}
Technological developments give rise to various kinds of influences in human life. This influence not only has a positive impact, but also has a negative impact because of the misuse of technology. One of the recent incidents is the widespread distribution of pornographic videos (sex tapes) played by artists or ordinary people, for the benefit of the spreader or as a medium for extorting objects in photos/videos. This paper aims to look at forms of legal protection against the ownership of personal data containing pornography and to see steps that private owners can take to protect their personal data. In this paper, the author uses a legal research method, which is a know-how activity (finding how), not just know-about (searching about). As a know-how activity, legal research is conducted to solve legal issues faced. In this study, it can be concluded that the Electronic Personal Data containing pornography can be protected by law as a scope for the personal interests of the object in the photo/video itself. However, the data must be maintained and stored so that there is no access from other parties who can disseminate the data. The owner of personal data has personal rights to his electronic personal data, if the personal data is in the hands of another person, then the right holder has the authority to do something or not to do something to his personal data. One of the protection measures that can be taken is the destruction of personal data to prevent data misuse.
\end{abstract}

Keywords: Private data, privacy, pornography

\begin{abstract}
ABSTRAK
Perkembangan teknologi memunculkan berbagai macam pengaruh di dalam kehidupan manusia. Pengaruh tersebut tidak hanya memberikan dampak positif, tetapi juga turut berkembang pula pengaruh negatif Sebagai dampak penyalahgunaan teknologi. Salah satu kejadian yang marak belakangan ini adalah maraknya penyebaran video porno (sex tape) yang diperankan oleh kalangan artis atau masyarakat biasa, demi keuntungan penyebar atau sebagai media pemerasan kepada objek di dalam foto/video. Tulisan ini memiliki tujuan untuk melihat bentuk perlindungan hukum terhadap kepemilikan data pribadi bermuatan pornografi dan melihat langkah yang dapat diambil pemilik pribadi untuk melindungi data pribadi miliknya. Pada tulisan ini, penulis menggunakan metode penelitian hukum, yaitu suatu kegiatan know-how (mencari bagaimana), bukan sekadar know-about (mencari tentang). Sebagai kegiatan know-how, penelitian hukum dilakukan untuk memecahkan isu hukum yang dihadapi. Dalam penelitian ini, dapat disimpulkan bahwa Data Pribadi Elektronik bermuatan pornografi dapat dilindungi oleh hukum sebagai lingkup untuk kepentingan pribadi objek di dalam foto/video sendiri. Namun data tersebut haruslah dijaga dan disimpan agar tidak ada akses dari pihak lain yang dapat menyebarluaskan data tersebut. Pemilik data pribadi memiliki hak pribadi terhadap data pribadi elektroniknya, apabila data pribadi tersebut berada di tangan orang lain, maka sebagai pemegang hak memiliki wewenang untuk melakukan sesuatu atau tidak melakukan sesuatu terhadap data pribadinya. Salah satu upaya perlindungan yang dapat dilakukan dengan pemusnahan data pribadi untuk mencegah penyalahgunaan data.
\end{abstract}

Kata Kunci: Data pribadi, privasi, pornografi

\section{PENDAHULUAN}

\section{Latar Belakang}

Dewasa ini, kita hidup di dalam era pertukaran informasi yang cepat. Manusia berlomba-lomba menciptakan teknologi yang mampu menembus ruang dan waktu untuk memudahkan berbagai aktivitas yang dilakukan. Salah satu penemuan tersebut adalah diciptakannya sebuah jaringan komunikasi yang dapat menghubungkan seluruh manusia di muka bumi dan mempercepat arus penyebaran informasi. Dapat kita sadari bersama, bahwa saat ini dunia sedang berada dalam era informasi, yang merupakan tahapan selanjutnya setelah era prasejarah, era agraris, dan era industri (Makarim, 2004). Untuk memahami konsep informasi, kita dapat melihat esensinya, bahwa suatu 
informasi berasal dari suatu data (semua fakta yang direpresentasikan sebagai input dalam bentuk teks, angka, gambar, suara, ataupun gerak), yang telah diproses ataupun mengalami perubahan bentuk dan/atau pertambahan nilai menjadi suatu bentuk yang lebih berarti sesuai konteksnya (Makarim, 2004). Dapat diartikan bahwa sebuah informasi merupakan hasil dari adanya pengolahan terhadap suatu data, oleh karena itu sebelum data diolah menjadi sebuah informasi dibutuhkan perhatian terhadap kepentingan orang lain serta kepentingan publik.

Sebuah data tentunya melekat dengan pemilik data tersebut. Oleh karenanya, data milik seseorang haruslah dilindungi dari berbagai tindakan penggunaan tanpa seizin pemilik data dan tindakan lain yang dapat menimbulkan kerugian bagi pemilik data. Data yang melekat pada diri seseorang, atau dapat dikatakan sebagai data pribadi memiliki keterkaitan dengan pengertian privasi yang melekat pada setiap manusia. Ronald Standler mengemukakan bahwa privasi merupakan suatu harapan bahwa informasi pribadi seorang individu yang bersifat rahasia tidak akan diungkapkan kepada pihak ketiga, dimana informasi tersebut dapat menyebabkan rasa malu atau tekanan mental atas hal-hal yang dianggap sensitif (Standler, 1996).

Perlindungan mengenai privasi sendiri memiliki keterkaitan dengan perlindungan data pribadi seseorang. Privasi mencakup di dalamnya berupa Data perorangan (personal data) dapat diartikan sebagai informasi yang sangat erat kaitannya dengan perorangan seperti informasi tentang data pribadi seseorang, data tentang kesehatan, keadaan keuangan, track record pekerjaan, track record kejahatan (Kantaatmadja, 2002). Pada dasarnya setiap informasi khususnya informasi pribadi seseorang merupakan harta milik dari orang tersebut, sudah sepatutnya dilindungi oleh hukum dari tindakan pengumpulan dan pengolahan informasi-informasi tersebut dari usaha-usaha yang melanggar privasi mereka (Makarim, 2004).

Muatan data pribadi sendiri tidak hanya terfokus nama, alamat serta track record pekerjaan, namun dapat juga bermuatan pornografi. Muatan pornografi sendiri berupa eksploitasi dan komersialisasi seks yang berupa pengumbaran ketelanjangan baik sebagian maupun seluruhnya, pengumbaran gerakan-gerakan erotis, serta pengumbaran aktivitas seksual sosok perempuan, remaja, maupun anak-anak yang hadir dalam produk media komunikasi, media massa, dan atau pertunjukkan (Soebagijo, 2008). Dewasa ini sedang marak-maraknya tindakan pornografi dengan melakukan penyebaran data pribadi disertai foto bermuatan erotis terhadap public figure, artis, influencer, maupun masyarakat biasa.

Muatan pornografi sendiri berupa eksploitasi dan komersialisasi seks yang berupa pengumbaran ketelanjangan baik sebagian maupun seluruhnya, pengumbaran gerakan-gerakan erotis, serta pengumbaran aktivitas seksual sosok perempuan, remaja, maupun anak-anak yang hadir dalam produk media komunikasi, media massa, dan atau pertunjukan (Soebagijo, 2008). Harus dipahami bahwa dalam kaitan mendefinisikan pornografi, pornografi adalah adanya elemen "bertujuan" atau dengan sengaja "bermaksud" membangkitkan gairah seksual seseorang yang menyaksikannya (Yunia, 2012). Indonesia sendiri telah memiliki Undang-Undang khusus mengenai pornografi yaitu Undang-Undang Nomor 44 Tahun 2008 Tentang Ponografi. Objek pornografi menurut Undang-Undang Pornografi sendiri berupa gambar, sketsa, foto, tulisan, suara bunyi, gambar bergerak, animasi, kartun, percakapan, gerak tubuh atau bentuk pesan lainnya melalui berbagai bentuk media komunikasi. Wujud kecabulan yang melekat pada suatu benda disebut sebagai benda pornografi. Benda pornografi itu sendiri berupa wujud bentuk gambar, sketsa, foto, tulisan, suara, bunyi, gambar bergerak, animasi, kartun, percakapan yang mengandung isi kecabulan (Chazawi, 2005). 
Di Indonesia sendiri telah banyak terjadi kasus penyebaran video seks yang diperankan oleh artis maupun masyarakat biasa. Salah satu kasus yang sempat menghebohkan adalah penyebarluasan video seks (lebih lanjut dikenal dengan sex tape) yang diperankan oleh AN, CT, dan LM serta yang belakangan ini sangat menghebohkan adalah penyebaran video seks yang diperankan GA dan MY. Aksi penyebaran sex tape ini dilakukan diberbagai macam media seperti Twitter dan Aplikasi Telegram. Bahkan sang pelaku mendapatkan keuntungan dari penyebaran sex tape artis ini. Sebagai kasus pembanding, Pengadilan tinggi daerah Koblenz, Jerman memerintahkan fotofoto intim harus dihapus apabila mitra pasangan meminta untuk itu. (Tim Internet Sehat, 2014) Seorang Pria mengambil foto erotis pasangannya, ketika hubungan asmaranya berakhir sang wanita meminta pria tersebut untuk menghapus foto erotisnya, namun Pria tersebut menolak sehingga wanita tersebut meminta bantuan hukum. Penghapusan data pribadi dapat dilakukan apabila data pribadi digunakan diluar tujuan dibuatnya data serta tidak dibutuhkannya lagi penyimpanan data tersebut terkait dengan tujuan dibuatnya data tersebut.

Diperlukan penafsiran hukum atau interpretasi peraturan Undang-Undang yang bertujuan untuk mencari dan menetapkan pengertian atas dalil-dalil yang tercantum dalam Undang-Undang sesuai dengan yang dikehendaki serta yang dimaksud oleh pembuat Undang- Undang (Soeroso, 2006). Metode penafsiran yang dapat digunakan yaitu penafsiran perbandingan. Penafsiran perbandingan ialah suatu penafsiran dengan membandingkan antara hukum lama dengan hukum positif yang berlaku saat ini, antara hukum nasional dengan hukum asing dan hukum kolonial (Soeroso, 2006). Berdasarkan hal-hal tersebut di atas, penulis melakukan penelitian tentang langkah preventif terhadap perlindungan data pribadi yang dikaitkan dengan tindakan penyebaran sex tape.

\section{Rumusan Masalah}

(a) Bagaimanakah perlindungan terhadap pemilik data pribadi yang memiliki konten pornografi di Indonesia?; (b) Bagaimanakah upaya yang dapat dilakukan seseorang untuk melindungi data pribadi miliknya menurut hukum positif di Indonesia?

\section{METODE PENELITIAN}

Menurut Marzuki (2005), metode penelitian terdapat dua tipe, pertama, metode penelitian empiris yaitu untuk menemukan kebenaran korespondensi atau sesuatu yang dapat dilihat dan kedua, metode penelitian hukum yaitu untuk menemukan kebenaran koherensi atau kesesuaian. Pada tulisan ini, penulis menggunakan metode penelitian hukum, yaitu suatu kegiatan know-how (mencari bagaimana), bukan sekadar know-about (mencari tentang). Sebagai kegiatan know-how, penelitian hukum dilakukan untuk memecahkan isu hukum yang dihadapi. Di sinilah dibutuhkan kemampuan untuk mengidentifikasi masalah hukum, melakukan penalaran hukum, menganalisis masalah yang dihadapi dan kemudian memberikan pemecahan atas masalah tersebut (Marzuki, 2005).

Penelitian hukum adalah suatu proses untuk menemukan aturan hukum, prinsip hukum, maupun doktrin hukum guna menjawab isu hukum yang dihadapi (Marzuki, 2005). Sifat penilitian yang dilakukan adalah bersifat penelitian preskriptif, yaitu suatu penelitian yang bertujuan untuk mendapatkan saran-saran mengenai apa yang harus dilakukan guna mengatasi masalah-masalah tertentu. Dalam penelitian hukum dikenal beberapa pendekatan. Pada penelitian ini penulis menggunakan pendekatan undang-undang (statute approach). Melalui pendekatan ini, penulis menelaah semua peraturan perundang-undangan dan regulasi yang bersangkut paut dengan isu hukum yang sedang ditangani (Marzuki, 2005). 
Sumber-sumber penelitian hukum dapat dibedakan menjadi sumber-sumber penelitian yang berupa bahan-bahan hukum primer dan bahan-bahan hukum sekunder. Bahan hukum primer merupakan bahan hukum yang bersifat autoritatif, artinya mempunyai otoritas. Bahan-bahan hukum primer terdiri dari perundang-undangan, catatan-catatan resmi atau risalah dalam pembuatan perundang-undangan dan dan putusan-putusan hakim. Bahan Hukum Primer yang digunakan dalam penelitian ini diantaranya, adalah: Undang-Undang Dasar Negara Republik Indonesia Tahun 1945, Undang-Undang Nomor 44 Tahun 2008 tentang Pornografi, dan UndangUndang Nomor 19 Tahun 2016 tentang Informasi dan Transaksi Elektronik. Adapun bahan-bahan hukum sekunder berupa semua publikasi tentang hukum yang bukan merupakan dokumen resmi. Publikasi tentang hukum meliputi buku-buku teks, kamus-kamus hukum, jurnal-jurnal hukum dan komentar-komentar atas putusan pengadilan.

Berdasarkan metode penelitian yang penulis gunakan, teknis pengumpulan data yang dilakukan adalah studi Pustaka yang dilakukan melalui pengumpulan dari bahan hukum primer dan bahan hukum sekunder. Teknis analisis bahan hukum yang penulis gunakan adalah metode deduktif. Penulis menjelaskan suatu hal yang bersifat umum, kemudian menariknya menjadi suatu kesimpulan yang khusus.

\section{HASIL DAN PEMBAHASAN Perlindungan Data Pribadi}

Data merupakan representasi formal suatu konsep, fakta, dam instruksi. Data adalah setiap informasi yang diproses melalui alat yang berfungsi menanggapi setiap informasi yang diberikan bagi tujuannya dan disimpan dengan tujuan dapat diproses. Data merupakan bahan baku dari informasi yang selanjutnya informasi merupakan makna data itu bagi manusia (Purwanto, 2007). Data sangat berkaitan dengan privasi, hal ini dikarenakan isi dari privasi merupakan informasi data pribadi. Hal ini merujuk pada salah satu konsep privasi yaitu ketakutan atas dibukanya informasi tentang pribadi seseorang akan sangat memengaruhi kebebasan orang tersebut untuk melakukan tindakan-tindakan tertentu (Makarim, 2004). Professor Alan Westin menyebutkan bahwa tidak ada definisi yang pasti dari privasi, namun dirinya mengartikan privasi merupakan kehendak seseorang untuk secara bebas serta sejauh mana orang tersebut akan membuka tentang dirinya dan kebiasaan kepada orang lain (Munir, 1999). Ronald B Standler mengartikan definisi dari privasi sendiri merupakan suatu harapan bahwa informasi pribadi seorang individu yang bersifat rahasia tidak akan diungkapkan kepada pihak ketiga, dimana informasi tersebut dapat menyebabkan rasa malu atau tekanan mental atas hal-hal yang dianggap sensitif. Informasi yang dimaksud adalah seperti fakta-fakta, foto-foto, atau video-video, serta pendapat yang memalukan (Ronald B Standler, 1996).

Pengertian mengenai hak pribadi (privacy right) dalam dunia internasional dimuat dalam The Universal Declaration of Human Right 1948 Article 12 yaitu, "No one shall be subjected to arbitrary interference with his privacy, family, home or correspondence, nor to attacks upon his honor and reputation. Everyone has the right to the protection of the law against such interference or attacks". Istilah informasi pribadi secara elektronik sendiri telah dituangkan dalam sebuah peraturan di Indonesia yaitu dalam Undang-Undang Nomor 11 Tahun 2008 tentang Informasi dan Transaksi Elektronik dengan istilah data pribadi. Peraturan di Indonesia turut mengakomodir mengenai definisi dari data pribadi ini sendiri, dalam Pasal 1 angka 27 Peraturan Pemerintah Nomor 82 Tahun 2012 tentang Penyelenggaraan Sistem dan Transaksi Elektronik yaitu, "Data Pribadi adalah data perseorangan tertentu yang disimpan, dirawat, dan dijaga kebenaran serta dilindungi kerahasiaannya". 
Data pribadi merupakan milik dari perseorangan yang berarti adanya hak oleh pemilik tersebut terhadap penggunaan serta perlindungan dari hal-hal yang merugikan pemilik. Sebuah data pribadi merupakan sebuah data tentang seseorang yang pada prinsipnya harus diberikan perlindungan agar tidak terjadi penyalahgunaan atau penggunaan dari hal yang tidak diinginkan. Akibat dari ketiadaan pengaturan mengenai perlindungan data pribadi, dapat terjadi berbagai kasus yang merugikan seperti (Dewi, 2009); Penyalahgunaan informasi perusahaan terhadap data dan informasi pelanggan yang diserahkan sebagai persyaratan transaksi bisnis, terjadinya kasus tanda penduduk yang berlainan antara data dan informasi yang sebenarnya, terjadinya kejahatan yang bermula dari pencarian data dan informasi seseorang, dan Pelanggaran privacy atas data dan informasi seseorang. Data pribadi sendiri merupakan milik dari perseorangan yang berarti adanya hak oleh pemilik tersebut terhadap penggunaan serta perlindungan dari hal-hal yang merugikan pemilik.

Hak itu sendiri mengandung unsur perlindungan dan kepentingan di dalamnya, hal itu karena setiap orang ingin haknya diakui serta tidak dikekang yang ditujukan untuk memenuhi kepentingannya. Hak ternyata tidak hanya mengandung unsur perlindungan dan kepentingan, melainkan juga kehendak (Rahardjo, 2006). Hak milik berhubungan dengan barang-barang yang dimiliki oleh seseorang yang biasanya bisa dialihkan, hak-hak pribadi berhubungan dengan kedudukan seseorang yang tidak pernah bisa dialihkan. Ciri- ciri yang melekat pada hak menurut hukum adalah sebagai berikut (Rahardjo, 2006), (1) Hak itu dilekatkan kepada seseorang yang disebut sebagai pemilik atau subjek dari hak itu. Ia juga disebut sebagai orang yang memiliki titel atas barang yang menjadi sasaran dari hak; (2) Hak itu tertuju kepada orang lain, yaitu yang menjadi pemegang kewajiban. Antara hak dan kewajiban terdapat hubungan korelatif; (3) Hak yang ada pada seseorang ini mewajibkan pihak lain untuk melakukan (commission) atau tidak melakukan (omission) sesuatu perbuatan. Ini bisa disebut sebagai isi dari hak; (4) Commission atau omission itu menyangkut sesuatu yang bisa disebut sebagai objek dari hak; (5) Setiap hak menurut hukum itu mempunyai titel, yaitu suatu peristiwa tertentu yang menjadi alasan melekatnya hak itu pada pemiliknya.

Privasi sebagai induk perlindungan sebuah data pribadi menyebutkan bahwa hak yang ada di dalam sebuah data pribadi berupa mengontrol informasi pribadi seseorang dan kemampuan untuk menentukan hal apa saja dan bagaimana informasi tersebut harus diperoleh dan digunakan. Negara Jerman menyatakan hal ini sebagai informational self-determination. Pada tahun 1983, Peradilan Konstitusional Jerman mengatur bahwa semua penduduk mempunyai hak informational selfdetermination (kemampuan seseorang untuk menentukan penggunaan informasi tentang dirinya). Sementara kebanyakan negara dengan undang-undang privasinya mempunyai gagasan tentang self-control (kontrol pribadi) (Makarim, 2004). Penentuan penggunaan informasi atau informational self-determination mencegah sesuatu informasi yang bersifat sensitif agar tidak berkembang atau tersebar ke pihak lain. Perlindungan data pribadi sangat penting untuk menjamin kebebasan dan penggunaan data pribadi seseorang. Disaat yang sama informational selfdetermination merupakan sebuah syarat agar dapat berkembang serta terciptanya tatanan komunikasi yang bebas dan demokratis. Jika seseorang tidak dapat dengan mudah mengawasi dan mengontrol mengenai data pribadinya yang dapat diakses oleh publik, serta tidak dapat menilai pengetahuan dari mitra bicaranya, maka dapat dihambat dengan menggunakan kebebasan yang dimiliki pemilik data tersebut. Hal tersebut kembali kepada dasar hak asasi manusia mengenai kebebasan perlindungan diri pribadi. Setiap individu harus dapat merasakan terlindungi dari gangguan hal-hal pribadi, lingkup dimana seseorang tersebut dapat merasa aman dari gangguan apapun. Negara hukum yang demokratis bergantung pada partisipasi seluruh warga untuk menghormati kebebasan individu masing-masing orang (Hornung \& Schnabel, 2009). 
Pengertian mengenai bentuk sebuah data pribadi disebutkan dalam Pasal 1 angka 4 UndangUndang Nomor 11 Tahun 2008 Tentang Informasi dan Transaksi Elektronik bahwa, "Dokumen Elektronik adalah setiap informasi elektronik yang dibuat, diteruskan, dikirimkan, diterima, atau disimpan dalam bentuk analog, digital, elektromagnetik, optikal, atau sejenisnya, yang dapat dilihat, ditampilkan dan/atau didengar melalui komputer atau sistem elektronik, termasuk tetapi tidak terbatas pada tulisan, suara, gambar, peta, rancangan, foto atau sejenisnya, huruf, tanda, angka, kode akses, simbol atau perforasi yang memiliki makna atau arti atau dapat dipahami oleh orang yang mampu memahaminya". Sebagai sebuah data pribadi elektronik dalam lingkup peraturan di Indonesia dianggap sebagai sebuah dokumen elektronik. Selanjutnya mengenai upaya perlindungan data pribadi terkait penggunaannya Undang-Undang ITE menyebutkan dalam Pasal 26 yaitu, "(1) Kecuali ditentukan lain oleh Peraturan Perundangundangan, penggunaan setiap informasi melalui media elektronik yang menyangkut data pribadi seseorang harus dilakukan atas persetujuan Orang yang bersangkutan; (2) Setiap Orang yang dilanggar haknya sebagaimana dimaksud pada ayat (1) dapat mengajukan gugatan atas kerugian yang ditimbulkan berdasarkan Undang-Undang ini". Penjelasan Pasal 26 menyebutkan perlindungan data pribadi merupakan salah satu bagian dari hak pribadi (privacy rights). Terkait penyebaran data bermuatan pornografi secara elektronik, diatur sebagai perbuatan yang dilarang dalam Pasal 27 ayat (1) Undang-Undang Informasi dan Transaksi Elektronik. Ketentuan pidana terkait pelanggaran Pasal 27 ayat (1) terdapat dalam Pasal 45 ayat (1) yaitu dipidana dengan penjara paling lama 6 (enam) tahun dan/atau denda paling banyak Rp 1.000.000.000,00 (satu miliar rupiah).

\section{Perlindungan Hukum Terhadap Pemilik Data Pribadi Elektronik Bermuatan Pornografi di Indonesia}

Pornografi merupakan permasalahan yang sangat kompleks. Terlebih perkembangan teknologi informasi saat ini dapat menunjang penyebaran pornografi ke berbagai macam lini dalam masyarakat mulai dari anak-anak hingga orang dewasa. Undang-Undang nomor 44 Tahun 2008 Tentang Pornografi memuat larangan berupa "membuat" dan "memiliki atau menyimpan" produk pornografi. Selanjutnya mengenai larangan membuat pornografi terdapat dalam Pasal 4 ayat (1) Undang-Undang Pornografi, yang berisi: "Setiap orang dilarang memproduksi, membuat, memperbanyak, menggandakan, menyebarluaskan, menyiarkan, mengimpor, mengekspor, menawarkan, memperjualbelikan, menyewakan, atau menyediakan pornografi yang secara eksplisit memuat: (a) persenggamaan, termasuk persenggamaan yang menyimpang; (b) kekerasan seksual; (c) masturbasi atau onani; (d) ketelanjangan atau tampilan yang mengesankan ketelanjangan; (e) alat kelamin; atau (f) pornografi anak". Lebih lanjut lagi, larangan memiliki dan menyimpan pornografi terdapat dalam Pasal 6 UU Pornografi, yang berisi: "Setiap orang dilarang memperdengarkan, mempertontonkan, memanfaatkan, memiliki atau menyimpan produk pornografi sebagaimana dimaksud dalam pasal 4 ayat (1), kecuali yang diberi kewenangan oleh peraturan perundang-undangan".

Penjelasan Pasal 4 ayat (1) dan Pasal 6 memberikan pembatasan terhadap tindakan "membuat" dalam Pasal 4 ayat (1) dan tindakan "memiliki atau menyimpan" dalam Pasal 6, dalam penjelasan pasal dijelaskan bahwa yang dimaksud dengan "membuat" dan "memiliki atau menyimpan" tidak termasuk untuk dirinya sendiri dan kepentingan sendiri. Berdasarkan putusan Mahkamah Konstitusi Nomor 48/PUU-VIII/2010 menurut Mahkamah, antara pasal dan penjelasan pasal tersebut bukanlah hal yang bertentangan melainkan pembatasan atau pengecualian. Apabila diperhatikan dengan cermat redaksi Pasal 4 ayat (1) yaitu larangan memproduksi, memperbanyak, menggandakan, menyebarluaskan, menyiarkan, mengimpor, mengekspor, menawarkan, memperjualbelikan, menyewakan atau menyediakan pornografi, merupakan perbuatan-perbuatan 
yang memang bukan untuk kepentingan sendiri, sehingga dalam Penjelasannya khusus kata "membuat" diberi pembatasan bahwa yang dimaksud adalah tidak termasuk "membuat" untuk dirinya sendiri dan kepentingan sendiri. Begitu pula Pasal 6 dan Penjelasannya tidak bertentangan satu sama lain, melainkan sebagai pembatasan atau pengecualian.

Pornografi memiliki unsur bertujuan atau dengan sengaja bermaksud membangkitkan gairah seksual. Diartikan bahwa pemanfaatan produk pornografi yang dilarang oleh Undang-Undang berupa pornografi yang melanggar norma dalam masyarakat seperti mengganggu ketertiban umum, serta larangan untuk membuat produk pornografi tidak termasuk hal yang dilarang selama digunakan untuk dirinya sendiri dan kepentingan sendiri (Yunia, 2012). Pada kasus yang menjerat NI, atau yang popular dikenal dengan AN, ia divonis karena berdasarkan fakta yang ditemui di persidangan, AN menyediakan dan menawarkan pornografi yang memuat suatu kegiatan persenggamaan dan ketelanjangan yang merupakan suatu tindak pidana. Perbuatan ini kemudian memberikan kesempatan pada orang lain untuk menyebarkan konten pornografi tersebut, hal ini sesuai dengan Undang-Undang Nomor 48 Tahun 2008 tentang Pornografi. Hal ini dikarenakan data pribadi tidak dimungkinkan untuk dibuka kepada khalayak umum, apabila telah terbuka kepada khalayak umum dan melukai kepentingan masyarakat maka hal tersebut tidak dapat dilindungi.

Terkait data elektronik bermuatan pornografi yang dimiliki artis GA dan MY, perbuatan persenggamaan yang dilakukan dan kemudian disimpan bukan merupakan pelanggaran. Hal ini dikarenakan data elektronik tersebut dibuat bukan untuk khalayak umum, melainkan untuk kepentingan pribadi. Data yang disimpan merupakan koleksi pribadi dan dilindungi, selama data elektronik bermuatan pornografi tidak digunakan dipertontonkan ke khalayak umum yang dapat menimbulkan terganggunya ketertiban umum. Perlindungan diri pribadi diberikan selama data elektronik berupa foto-foto erotis tersebut dapat terjaga dengan aman serta penuh kehati-hatian. Selain itu perlindungan terhadap data pribadi bermuatan pornografi dapat diberikan apabila pemilik data tersebut tidak dengan ceroboh atau sengaja memberikan kesempatan kepada pihak lain untuk mengetahui keberadaan serta bentuk dari data tersebut, hal ini yang biasanya dapat memicu terjadinya penyebaran data elektronik bermuatan pornografi.

Kerugian yang didapat oleh korban atas penggunaan data elektronik pribadinya dapat dimintakan penggantian kerugian terhadap penggunaan data pribadi tanpa seizin dirinya, hal itu termuat dalam pasal 26 Undang-Undang ITE, yang berisi: “(1) Kecuali ditentukan lain oleh Peraturan PerundangUndangan, penggunaan setiap informasi melalui media elektronik yang menyangkut data pribadi seseorang harus dilakukan atas persetujuan Orang yang bersangkutan; (2) Setiap Orang yang dilanggar haknya sebagaimana dimaksud pada ayat (1) dapat mengajukan gugatan atas kerugian yang ditimbulkan berdasarkan Undang-Undang ini". Rancangan Undang-Undang perlindungan data pribadi sendiri telah memuat pengertian mengenai data pribadi sensitif. Definisi dari data pribadi sensitif itu sendiri adalah data pribadi yang memerlukan perlindungan khusus yang terdiri dari data yang berkaitan dengan agama/keyakinan, kesehatan, kondisi fisik dan kondisi mental, kehidupan seksual, data keuangan pribadi dan data lainnya yang mungkin dapat membahayakan dan merugikan privasi subjek data. 


\section{Tindakan yang Dapat Diambil Dalam Melindungi Data Pribadi terhadap Tindakan Penyebaran Sex Tape}

Fenomena penyebaran sex tapes sedang sangat berkembang di luar negeri bahkan di Indonesia, namun kehadirannya sendiri diakibatkan penyalahgunaan perkembangan teknologi informasi. Prinsip utama fenomena ini adalah penyebaran data dengan muatan pornografi tanpa sepengetahuan objek data. Perbuatan ini dilakukan dengan berbagai motif, mulai dari merugikan objek foto, balas dendam, pemerasan, dan mendapatkan keuntungan dengan menjual data pribadi bermuatan pornografi melalui aplikasi twitter, telegram, dan aplikasi media sosial lainnya. Upaya preventif yang dimaksud merupakan bentuk pencegahan sebelum terjadinya tindakan penyebaran pornografi itu terjadi. Perbandingan kasus yang terjadi di Jerman mengenai pemusnahan atau penghapusan data elektronik berupa foto erotis merupakan bentuk dari langkah preventif mencegah penyebaran pornografi melalui tindakan penyebaran sex tapes.

Sebagai sebuah data elektronik, melihat Undang-Undang Nomor 11 Tahun 2008 Tentang Informasi dan Transaksi Elektronik, pelarangan penyebaran data elektronik yang bermuatan kesusilaan diatur dalam Pasal 27 ayat (1) Undang-Undang ITE, yang berisi: "Setiap Orang dengan sengaja dan tanpa hak mendistribusikan dan/atau mentransmisikan dan/atau membuat dapat diaksesnya Informasi Elektronik dan/atau Dokumen Elektronik yang memiliki muatan yang melanggar kesusilaan". Pasal 27 ayat (1) ini bersifat sebuah pelarangan yang berarti memerintahkan agar tidak melakukan tindakan tersebut. Melalui Pasal tersebut merupakan salah satu tindakan melindungi penyalahgunaan data elektronik. Diperlukan tindakan pemusnahan data sebagai upaya preventif yang memastikan data tersebut tidak akan disalahgunakan, karena wujudnya telah tiada. Sebagai perbandingan peraturan berdasarkan Undang-Undang perlindungan data pribadi Negara Jerman Bundesdatenschutzgesetz (BDSG) Section 35 (2) bahwa penghapusan data pribadi dapat dilakukan apabila data pribadi digunakan diluar tujuan dibuatnya data serta tidak dibutuhkannya lagi penyimpanan data tersebut terkait dengan tujuan dibuatnya data tersebut, penghapusan dilakukan berdasarkan permintaan subjek data. Melihat Undang-Undang Nomor 44 Tahun 2008 Tentang Pornografi terdapat pasal mengenai pemusnahan produk pornografi dalam Pasal 28 Undang-Undang Pornografi, yang mengatakan: (1) Pemusnahan dilakukan terhadap produk pornografi hasil perampasan; (2) Pemusnahan produk pornografi sebagaimana dimaksud pada ayat (1) dilakukan oleh penuntut umum dengan membuat berita acara yang sekurangkurangnya memuat: a. Nama media cetak dan/atau media elektronik yang menyebarluaskan pornografi; b. Nama, jenis, dan jumlah barang yang dimusnahkan; c. Hari, tanggal, bulan, dan tahun pemusnahan; d. Keterangan mengenai pemilik atau yang menguasai barang yang dimusnahkan". Pemusnahan menurut Pasal ini dilakukan terhadap produk pornografi hasil perampasan. Perampasan sendiri menurut Undang-Undang Nomor 1 Tahun 2006 Tentang Bantuan Timbal Balik Dalam Masalah Pidana, adalah upaya paksa pengambilalihan hak kekayaan atau keuntungan yang telah diperoleh, atau mungkin telah diperoleh orang lain dari tindak pidana yang dilakukannya, berdasarkan putusan pengadilan di Indonesia atau negara asing.

John Locke berpendapat bahwa setiap orang memiliki harta milik dalam dirinya dan karenanya menikmati hak untuk mengontrol dan mendominasi hasil dari dirinya tersebut. Teori ini melekatkan hak kepada seseorang yang disebut sebagai pemilik atau subyek dari suatu hak (Sidharta \& Mochtar, 2000). Sebagai pemilik hak, maka memiliki kewenangan yang mewajibkan pihak lain untuk melakukan (commission) atau tidak melakukan (omission) sesuatu perbuatan terhadap objek dari hak tersebut. Mengenai hak tersebut dapat disandingkan dengan kewenangan terhadap hak pribadi dikaitkan terhadap prinsip-prinsip perlindungan data pribadi, prinsip the right to be forgotten seperti yang ada dalam data protection di Eropa, dalam prinsip ini masyarakat berhak untuk meminta suatu informasi untuk dihapus jika informasi tersebut "inadequate, 
irrelevant or no longer relevant". Penghapusan data dapat dilakukan saat penggunaan data pribadi tidak sesuai kepentingan serta tidak sesuai dengan tujuan awal dari dibuatnya data tersebut. Prinsip ini dapat disandingkan dengan prinsip Informational Self Determination, kemampuan seseorang untuk menentukan penggunaan informasi tentang dirinya. Langkah preventif yang dapat dilakukan dapat berupa pemusnahan data pribadi untuk mencegah terjadinya penyebaran data pribadi elektronik bermuatan pornografi tersebut.

Fenomena penyebaran sex tape sangat marak terjadi di luar negeri bahkan di Indonesia, namun fenomena ini sendiri merupakan akibat dari penyalahgunaan perkembangan teknologi informasi. Dalam penyebaran sex tape ini, video disebar tanpa sepengetahuan dari objek. Aksi penyebaran pun didasari untuk memberikan keuntungan kepada penyebar, serta merugikan objek foto atau video. Bahkan dalam kasus lain digunakan untuk memeras obyek yang ada di dalam gambar atau video. Upaya preventif yang dimaksud merupakan bentuk pencegahan sebelum terjadinya tindakan penyebaran pornografi itu terjadi. Perbandingan kasus yang terjadi di Jerman mengenai pemusnahan atau penghapusan data elektronik berupa foto erotis merupakan bentuk dari langkah preventif mencegah penyebaran pornografi melalui tindakan penyebaran sex tape.

Sebagai sebuah data elektronik, melihat Undang-Undang Nomor 11 Tahun 2008 Tentang Informasi dan Transaksi Elektronik, pelarangan penyebaran data elektronik yang bermuatan kesusilaan diatur dalam Pasal 27 ayat (1) Undang-Undang ITE, "Setiap Orang dengan sengaja dan tanpa hak mendistribusikan dan/atau mentransmisikan dan/atau membuat dapat diaksesnya Informasi Elektronik dan/atau Dokumen Elektronik yang memiliki muatan yang melanggar kesusilaan". Pasal 27 ayat (1) ini bersifat sebuah pelarangan yang berarti memerintahkan agar tidak melakukan tindakan tersebut. Melalui Pasal tersebut merupakan salah satu upaya melindungi penyalahgunaan data elektronik, namun Pasal tersebut tidak memfokuskan kepada sebuah data pribadi elektronik yang sifatnya merupakan privasi seseorang, tetapi sifatnya lebih terhadap data elektronik secara general. Diperlukan sebuah upaya pemusnahan data sebagai sebagai sebuah upaya preventif yang memastikan bahwa data tersebut tidak akan disalahgunakan karena wujudnya telah tiada, serta tidak dapat dibentuk kembali. Hal ini seperti yang terjadi dalam putusan Pengadilan tinggi daerah Koblenz di Jerman, adanya sebuah keputusan untuk memusnahkan data pribadi elektronik bermuatan pornografi.

Berdasarkan Undang-Undang perlindungan data pribadi Negara Jerman Bundesdatenschutzgesetz (BDSG) Section 35 (2) bahwa penghapusan data pribadi dapat dilakukan apabila data pribadi digunakan diluar tujuan dibuatnya data serta tidak dibutuhkannya lagi penyimpanan data tersebut terkait dengan tujuan dibuatnya data tersebut, penghapusan dilakukan berdasarkan permintaan subjek data5. Sebagai sebuah data pribadi elektronik bermuatan pornografi, melihat UndangUndang Nomor 44 Tahun 2008 Tentang Pornografi terdapat pasal mengenai pemusnahan produk pornografi, yaitu Pasal 28 Undang-Undang Pornografi. Pemusnahan menurut Pasal ini dilakukan terhadap produk pornografi hasil perampasan. Perampasan sendiri menurut Undang-Undang Nomor 1 Tahun 2006 Tentang Bantuan Timbal Balik Dalam Masalah Pidana adalah upaya paksa pengambilalihan hak kekayaan atau keuntungan yang telah diperoleh, atau mungkin telah diperoleh orang lain dari tindak pidana yang dilakukannya, berdasarkan putusan pengadilan di Indonesia atau negara asing.

John Locke berpendapat bahwa, setiap orang mempunyai harta milik di dalam dirinya dan karenanya menikmati hak untuk mengontrol dan mendominasi hasil dari dirinya tersebut. Pada Kasus AN-LM-CT dan GA-MY, perbuatan sang penyebar video sex tape dapat dikatakan sebagai perampasan hak. Hal ini dikarenakan penyebar video telah mengambil alih hak kekayaan, yakni 
berupa hak pribadi dari foto/video yang diambil yang merupakan hasil dari diri masing-masing artis tersebut. Selain itu, sang penyebar video telah mencederai hak pribadi para artis tersebut, pada teori Hak dimana hak dilekatkan kepada seseorang yang disebut sebagai pemilik atau subjek dari hak. Sebagai pemilik hak, maka para artis tersebut memiliki kewenangan yang mewajibkan pihak lain untuk melakukan atau tidak melakukan sesuatu perbuatan terhadap objek dari hak tersebut. Tetapi, sang penyebar video melakukan tindakannya (menyebarkan video) tidak berdasarkan kewenangan dari hak yang dimiliki para artis yang ada di dalam video sex tape tersebut.

Sampai saat ini belum ada suatu undang-undang yang khusus mengatur mengenai upaya preventif terhadap bocornya suatu data pribadi. Dalam kaitannya dalam permasalahan ini, hukum positif yang ada saat ini hanya mengakomodasi bentuk sebagai sebuah data elektronik dan produk pornografi. Berbicara mengenai upaya preventif, diperlukan adanya suatu peraturan khusus yang memuat prinsip the right to be forgotten seperti di Eropa yang memungkinkan masyarakat untuk meminta dihapusnya suatu data jika informasi yang dikandung inadequate, irrelevant, or no longer relevant. Penghapusan terhadap suatu data pribadi dapat dilaksanakan jika penggunaan data pribadi tidak sesuai dengan kepentingan dan tidak sesuai dengan tujuan awal dibuatnya data tersebut (Commision, 2015). Hal ini berkenaan dengan prinsip informational self determination yang memiliki arti bahwa seseorang memiliki kemampuan untuk menentukan penggunaan informasi tentang dirinya. Upaya preventif dapat dilakukan dengan dimusnahkannya data pribadi bermuatan pornografi guna mencegah disebarkannya data pribadi tersebut. Pada kasus penyebaran sex tapes para artis ini, mereka yang menjadi korban penyebaran data pribadi bermuatan pornografi dapat meminta dimusnahkannya data tersebut yang merupakan data pribadi para korban dan tersimpan di perangkat elektronik masing-masing artis yang menjadi objek dalam data tersebut. Pemusnahan juga dapat dilakukan oleh para artis tersebut dengan menganggap bahwa video-video tersebut dapat mengancam dirinya karena dapat digunakan tidak sesuai dengan tujuan awal pembuatannya, yakni untuk koleksi sendiri dan kepentingan pribadi.

Tindakan penyebaran video sex tapes merupakan pelanggaran hukum. Hal ini dikarenakan pelaku dengan sengaja menyebarkan data tersebut kepada masyarakat sebagai pihak ketiga melalui media sosial. Hal ini mengakibatkan kehebohan dan dilanggarnya ketertiban umum di masyarakat. Tindakan ini juga melanggar hak pribadi para korban sebagai objek dalam data tersebut. Berdasarkan kasus pembanding yang terjadi di Hesse, Jerman, Pengadilan Tinggi Koblenz menyatakan hak pribadi lebih besar dibandingkan dengan hak fotografer. Pada kasus para artis mereka sebagai objek dari video sex tapes memiliki hak pribadi terhadap isi video tersebut, bukan pelaku penyebar. Para korban dapat mengajukan gugatan perdata kepada penyebar atas kerugian yang dialami, hal ini sesuai dengan Pasal 26 UU ITE ayat (2), yang menyebutkan "Setiap Orang yang dilanggar haknya sebagaimana dimaksud pada ayat (1) dapat mengajukan gugatan atas kerugian yang ditimbulkan berdasarkan Undang-Undang ini”.

Jika kita merujuk pada UU Pornografi, tindakan penyebar video dapat dikategorikan sebagai "membuat dan menyebarluaskan pornografi" (Pasal 4 ayat 1). Hal ini dikarenakan penyebar video dengan itikad tidak baik menyebarluaskan secara umum video sex tape para artis kepada pihak ketiga. Tindakannya tersebut telah melanggar norma dalam masyarakat serta mengganggu ketertiban umum. Selanjutnya, sang penyebar dengan sengaja menyebarkan video sex tape ke media WhatsApp dan Telegram sehingga dapat diaksesnya data elektronik bermuatan konten pornografi tersebut, yang seharusnya dijaga dan diamankan untuk kepentingan pribadi objek. Tindakan ini melanggar Pasal 29 UU Pornografi yaitu, "Setiap orang yang memproduksi, membuat, memperbanyak, menggandakan, menyebarluaskan, menyiarkan, mengimpor, 
mengekspor, menawarkan, memperjualbelikan, menyewakan, atau menyediakan pornografi sebagaimana dimaksud dalam Pasal 4 ayat (1) dipidana dengan pidana penjara paling singkat 6 (enam) bulan dan paling lama 12 (dua belas) tahun dan/atau pidana denda paling sedikit Rp 250.000.000,00 (dua ratus lima puluh juta rupiah) dan paling banyak Rp 6.000.000.000,- (enam miliar rupiah)".

Selain itu sebagai sebuah data elektronik tidak diperbolehkan adanya pendistribusian dokumen elektronik yang memiliki muatan asusila. Penyebaran data bermuatan asusila secara elektronik, diatur sebagai perbuatan yang dilarang dalam Pasal 27 ayat (1) Undang-Undang Informasi dan Transaksi Elektronik yaitu, "Setiap Orang dengan sengaja dan tanpa hak mendistribusikan dan/atau mentransmisikan dan/atau membuat dapat diaksesnya Informasi Elektronik dan/atau dokumen elektronik yang memiliki muatan yang melanggar asusila”. Ketentuan pidana terkait pelanggaran Pasal 27 ayat (1) terdapat dalam Pasal 45 ayat (1) yaitu dipidana dengan penjara paling lama 6 (enam) tahun dan/atau denda paling banyak Rp 1.000.000.000,00 (satu miliar rupiah).

\section{KESIMPULAN DAN SARAN}

Berdasarkan paparan yang penulis sampaikan, terdapat dua kesimpulan yang dapat disampaikan. Pertama, data Pribadi Elektronik bermuatan pornografi dapat dilindungi oleh hukum sebagai lingkup untuk kepentingan pribadi objek di dalam foto/video sendiri. Melihat Pasal 4 ayat (1) dan Pasal 6 Undang-Undang Nomor 44 Tahun 2008 tentang Pornografi, maksud dari "membuat" dan "memiliki atau menyimpan" mendapat pengecualian apabila ditujukan untuk dirinya sendiri dan kepentingan sendiri. Bentuk yang bersifat untuk diri sendiri tersebut harus dijaga dengan penuh kehati-hatian dalam penyimpanannya oleh pemilik data pribadi. Data pribadi elektronik tersebut tidak boleh dengan kecerobohannya dapat diketahui oleh pihak lain yang dapat terbukanya kesempatan untuk menyebarluaskan serta penggunaan tanpa sepengetahuan pemilik data pribadi.

Kedua, tindakan hukum preventif yang dilakukan untuk mencegah tindakan penyebaran sex tape merebak serta dapat merugikan secara materiil serta mental pihak korban yang pada umumnya kaum wanita. Tindakan preventif dalam peraturan di Indonesia bersifat pelarangan, berarti tindakan tersebut tidak boleh untuk dilakukan. Melihat Pasal 27 ayat (1) Undang-Undang ITE, dilarangnya untuk membuat dapat diaksesnya sebuah informasi elektronik memuat kesusilaan, bagi yang melanggar dikenakan sanksi pidana. Tindakan preventif yang tepat yaitu berupa pemusnahan, apabila telah dimusnahkan maka data tersebut telah tiada dan tidak dapat digunakanTindakan Hukum apabila telah terjadi tindakan penyebaran sex tape terhadap data pribadi seseorang yaitu dengan menggunakan pasal 4 ayat (1) Undang-Undang Pornografi sebagai tindakan menyebarluaskan pornografi yang apabila melakukan tindakan tersebut dapat dijerat sanksi pidana. Korban juga dapat mengajukan gugatan perdata atas kerugian yang dialaminya.

\section{Saran}

Berdasarkan kesimpulan yang penulis sampaikan, terdapat sara-saran yang dapat penulis rekomendasikan. Pertama, perlu dibuatnya sebuah peraturan mengenai perlindungan data pribadi yang memuat perlindungan terhadap data pribadi sensitif. Rancangan Undang-Undang Perlindungan Data Pribadi sendiri telah memuat mengenai data pribadi sensitif yang memerlukan perlindungan khusus yang didalamnya terdapat kehidupan seksual, namun mekanisme perlindungannya sendiri belum dijelaskan secara detail dalam RUU Perlindungan Data Pribadi. Diperlukan penjelasan mengenai maksud perlindungan khusus terhadap data pribadi sensitif tersebut. Hal ini diperlukan untuk mempertegas unsur untuk kepentingan pribadi terhadap sebuah data pribadi bermuatan pornografi secara jelas agar tidak menimbulkan permasalahan yang sama 
kedepannya. Pembahasan mengenai RUU Perlindungan Data Pribadi harus segera dilaksanakan dan segera disahkan mengingat kemajuan teknologi yang dapat menimbulkan bahaya terhadap data pribadi seseorang.

Kedua, perlindungan serta pencegahan terhadap data pribadi sangat diperlukan mengingat kemajuan teknologi saat ini. Peraturan yang ada saat ini seperti Undang-Undang ITE dan UndangUndang Pornografi belum secara jelas mengatur mengenai keberadaan data pribadi. Pengaturan tersebut diperlukan setelah dilakukan perbandingan hukum mengenai perlindungan data pribadi di Jerman dan Indonesia, dalam peraturan di Negara Jerman dimana Undang-Undang pada negara tersebut telah mampu mengakomodir prinsip-prinsip perlindungan data pribadi serta hak pribadi, selanjutnya Indonesia sebaiknya mengikuti tindakan yang telah dilakukan oleh Negara Jerman dengan membuat sebuah Undang-Undang Perlindungan Data Pribadi yang mampu mengakomodir prinsip-prinsip perlindungan data pribadi seseorang.

Ucapan Terima Kasih (Acknowledgment)

Penulis mengucapkan terima kasih kepada semua pihak yang telah membantu dan berkontribusi dalam penulisan artikel ini, baik yang memberikan kontribusi berupa dana maupun ide-ide kritis. Semoga makalah ini dapat bermanfaat secara teoritis dan praktis untuk penambahan dan pengembangan ilmu pengetahuan khususnya di bidang hukum.

\section{REFERENSI}

Chazawi, A. (2005). Tindak pidana mengenai kesopanan. Jakarta: PT. Raja Grafindo Persada.

Commision, E. (2015, November 27). Data protection. European Commision. https://ec.europa.eu/info/law/law-topic/data-protection_en

Dewi, S. (2009). Cyberlaw: Perlindungan privasi atas informasi pribadi dalam e-commerce menurut hukum internasional. Widya Padjajaran.

Hornung, G., \& Schnabel, C. (2009). Data protection in Germany I: The population census decision and the right to informational self-determination. Universitat Passau. http://www.uni-

passau.de/fileadmin/dateien/fakultaeten/jura/lehrstuehle/hornung/Hornung___Schnabel__ Data_protection_in_Germany_I_CLSR_2009_84.pdf

Kantaatmadja, M. K. (2002). Cyberlaw: Suatu pengantar. Elips.

Makarim, E. (2004). Kompilasi hukum telematika. PT Raja Grafindo Persada.

Marzuki, P. M. (2005). Metode penelitian hukum. Kencana.

Munir, A. B. (1999). Cyber law, Policies and Challenges. Butterworths Asia.

Purwanto. (2007). Penelitian Tentang perlindungan hukum data digital. Badan Pembinaan Hukum Nasional Departemen Hukum dan Hak Asasi Manusia.

Rahardjo, S. (2006). Ilmu hukum. Citra Aditya Bakti.

Standler, R. B. (1996, September). Privacy law in the USA. rbs2.com. http://rbs2.com/privacy.html Undang-Undang Dasar Negara Republik Indonesia Tahun 1945. Indonesia.

Undang-Undang Nomor 1 Tahun 2006 Tentang Bantuan Timbal Balik Dalam Masalah Pidana. Indonesia.

Undang-Undang Nomor 19 Tahun 2016 Tentang Informasi dan Transaksi Elektronik. Indonesia. Undang-Undang Nomor 44 Tahun 2008 Tentang Pornografi. Indonesia.

Tim Internet Sehat. (2014, n.d). Foto Intim harus dihapus di akhir hubungan. Internet Sehat. http://internetsehat.id/2014/05/foto-intim-harus-dihapus-di-akhir-hubungan/

Sidharta, A., \& Mochtar, K. (2000). Pengantar ilmu hukum: Suatu pengenalan pertama ruang lingkup berlakunya ilmu hukum. Alumni.

Soebagijo, A. (2008). Pornografi dilarang tapi dicari. Gema insani. 
Soeroso. (2006). Pengantar ilmu hukum. Sinar Grafika.

Yunia, F. (2012). Studi kasus Putusan Pengadilan Tinggi Np. 104/PID/2010/PT.DKI mengenai membuat atau menggandakan VCD/DVD pornografi anak [Skripsi, Universitas Padjadjaran]. 